\title{
Substantiation of the method ensuring the safe development of the pit reserves of kimberlite ore deposits in the conditions of the Udachny mine
}

\author{
K. A. Anisimov, V. P. Zubov \\ Saint Petersburg Mining University, 2, 21 st Line, St Petersburg 199106, Russia
}

\begin{abstract}
The paper discusses the features of the development of pit reserves of the Udachnaya diamondiferous pipe which consists of two closely spaced ore bodies under the protection of a moving ore-rock massif (a safety cushion). Low stability of the rock massif located between the ore bodies is indicated. Such low stability is caused by the presence of areas of increased intensity of fracturing and low coherence zones in the massif; it is also caused by the mutual impact of mining operations carried out in closely located ore bodies. A conclusion is made about the danger of collapse of sizeable rock blocks from the edge zones of the rock massif located between the ore bodies onto the safety cushion. In this case, individual rock blocks can be $0.4-0.6$ tons or more, the drop height is up to 600-700 m. Impact blows on the safety cushion when rock blocks collapse onto it can cause a disruption of underground mine workings stability and occurrence of dangerous pressure drops at the outlet of air waves from the safety cushion into the underground mine workings. A method for preventing dangerous impact blows is proposed, which consists in the forced collapse (with certain parameters) of the edge part of the rock massif located between the ore bodies, onto the safety cushion.
\end{abstract}

\section{INTRODUCTION}

As of 2020, the intermediate stage of the combined development of the deposit has been completed at Udachnaya kimberlite pipe. Open pit development of the part of the deposit adjacent to the surface has been completed. Currently, the deposit pit reserves are being developed. To ensure safe underground mining, a safety cushion was formed at the bottom of the open pit (Fig. 1) [1].

According to the solution specified in the Technical Regulations, the following mining methods for the pit reserves extraction were adopted:

1.Method of level caving with one-stage excavation and areal ore drawing for development of the deposit reserves to the level of $-580 \mathrm{~m}[2,3]$;

2.Method of sublevel caving with side ore drawing for the completion of the pit sides mining and formation of the necessary volume of safety cushion rock [4]. 


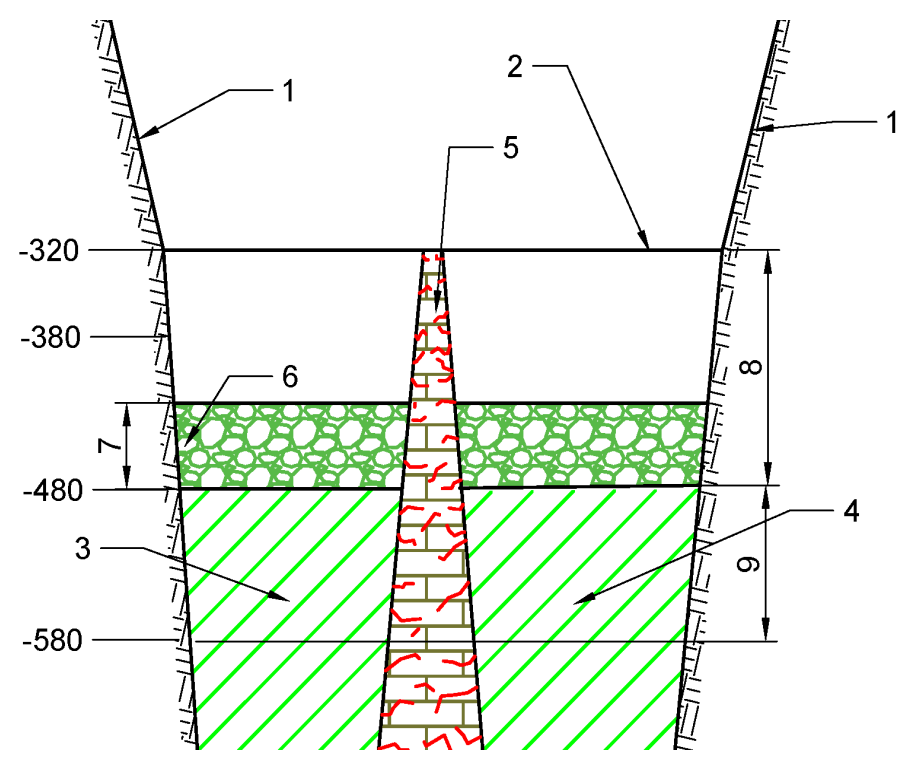

Fig. 1. Safety cushion for the Udachny Mine: 1- sides of the pit; 2- bottom of the pit at -320m; 3Western Ore Body (WOB); 4- Eastern Ore Body (EOB); 5- inter-ore pillar; 6- safety cushion; 7safety cushion thickness $\mathrm{h}=55 \mathrm{~m} ; 8$ - distance from the bottom of the pit to the bottom boundary of the 2nd mining floor $\mathrm{h}=160 \mathrm{~m}$; 9 - height of 3 rd mining floor $\mathrm{h}=100 \mathrm{~m}$.

The moving safety ore massif (Fig. 1 - 6) is formed partly from the pre-collapsed reserves of the near-side pit area, partly from the caved ore from the bottom of the open pit, and partly from the transported waste rock left in place. Thisore-bearing massif "safety cushion" gradually lowers following mining operations. It is planned to develop mining of the main ore reserves under the pit bottom under the protection of this safety cushion $[5,6$, 7]. In so doing, these safety cushion reserves are temporarily idle reserves; their extraction is planned during the development of the2nd phasereserves. Currently, St. Petersburg Mining University is conducting research to develop a safe and cost-effective technology for this $[8,9]$.

Analysis of the actual flow scheme at the Udachny Mine showed that the rock massif located between EOB and WOB is one of the factors that will have a significant impact on the safety of the underground mining operations. The main workings ofproduction horizons $(-380,-480$ and $-580 \mathrm{~m})$ pass through this rock massif [10].

This rock massif has a deformation structure in the zones of contact with kimberlite. This massif has a variety of fracture systems with an interval of 0.4-0.7 meters to 5 meters. The facture length is up 50 meters [11].

During mining operations with the help of ore caving, this massif will gradually be exposed, while the front of the excavation is lowered, and the safety cushion is lowered. At the same time, horizontal stresses in the rock massif will gradually decrease, which can cause instability in the strength and integrity of the rock massif [12]. When the massif located between the EOB and WOB has a certain height of its outcropping and has increased disturbance, there is a probability of triggering the processes of uncontrolled collapse of this massif rocks onto the subjacent safety cushion.

Impacts on the safety cushion when rock blocks collapse onto it can cause a disruption of the underground mine workings stability and the occurrence of dangerous pressure drops at the outlet of air waves from the safety cushion into the underground workings. 
The purpose of the study is to develop organizational and technical measures for ensuring the safety of the underground mining under the safety cushion.

\section{GEOLOGICAL ENVIROMENT}

The Udachnaya kimberlite pipe is a pillar-like vertical deposit that branches into two cone-shaped ore bodies, WOB and EOB. Limestones and dolomites compose the host rocks surrounding the ore bodies. The host rocks have horizontal bedding. The gentle bedding of sedimentary rocks, which is common for this region, near the pipe is replaed by areas of increased fracturing, zonesof crushing, and areas of disjunctive dislocations. The zone of fracturing of the host rocks and kimberlite rocks forms a strip ranging from a few meters to several tens of metersaround the pipe (Fig. 2).

The values of all physical and mechanical properties of the kimberlite rocks of WOB and EOB change by a factor of 1.1 - 6 with an increase in the occurrence depth from -320 to $-1,080$ meters. The average bulk density of the rocks atdeeper levels of the field (lvl -280 $\mathrm{m} /-1080 \mathrm{~m}$ ) varies from 2.57 to $2.66 \mathrm{ton} / \mathrm{m} 3$. In terms of uniaxial compressive strength, the kimberlites of EOB and WOB are soft $(\sigma=10-35 \mathrm{MPa})$ and very soft $(\sigma=4-10 \mathrm{MPa})$ rocks [13].

The strength coefficient of kimberlites ranges from 5 to 7 , and for the host rocks - from 1 and 8 (Protodyakov's scale). It was found that the strength coefficient has the lowest values in the crushing zones; less often, it has the lowest values in the zones of the hydrothermal alterations, and its highest values correspond to intensely silicified rocks [14, 15].

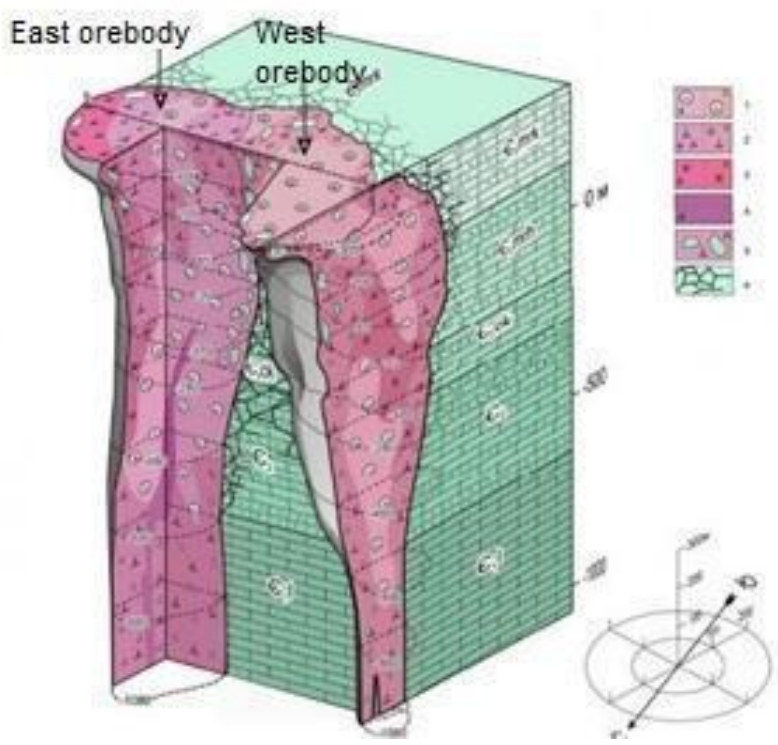

Fig. 2. Geological structure of the kimberlite pipe (G.S. Von der Flaas representation): 1 - autolithic kimberlite breccia (phase III); 2 - kimberlite breccia (II); 3 - kimberlite breccia of the massive structure (phase I); 4 - porphyritic kimberlite (phase IV); 5 - kimberlite breccia with large xenoliths of host rocks; 6 - crushing area of host rocks.

\section{RESEARCH}


In the course of the development of the EOB and WOB, specialists noted various factors complicating the development of the Udachnaya mine:

1. Possibility of freezing of fragments of rocks, which can result in freezing of the massif, and, subsequently, in a sudden collapse of the massif evolving in the result of a rock blow [17]. The collapse of pieces of rock onto the safety cushion can also trigger these processes [18]. 2. The presence in the massif of kimberlites and host rocks of increased fracturing zones, dangerous low-coherence zones caused by various geological, hydrological, hydro-geo-mechanical, geo-mechanical, and other factors [19], which reduces the stability of the massifs [20].

3. Combined impact of mining in EOB and WOB on inter-ore stability [21].

The bottom of the pit was destroyed by the underground mining operations, and a movable safety ore-rock cushion was formed to ensure the safety of the subjacent mining operations.

As of 2020, the intermediate stage of the combined development of the deposit has been completed at Udachnaya kimberlite pipe. Open pit development of the part of the deposit adjacent to the surface has been completed, extraction of the adjacent deposit part reserves by underground mining has been completed. The bottom of the pit was destroyed by the mining operations beneath the bottom, and an ore-rock movable safety cushion was formed to ensure the safety of the underlying mining operations.

\section{COMPLICATING FACTORS OF MINING OPERATIONS}

Research results of ALROSA, GipronickelR\&D Institute, theInstitute of Mining of the Ural Branch of the Russian Academy of Sciences, etc. confirm the earlier conclusion made by the authors of this article that the rock massif located between EOB and WOB is object of increased danger [22].

In 2017, theInstitute of Mining of the Ural Branch of the Russian Academy of Sciences carried out calculations to determine the optimal thickness of the safety cushion (Fig. 1). In order to determine the thickness of the cushion, the following negative factors which can affect mining operations were calculated: the aerodynamic connection of the mine with the open-pit, direct access of brines and water to the underground mines, impact blows of various types in the form of spot collapses and slides of the pit edges of a given volume onto the safety cushion.

However, these studies do not contain information on the danger posed by the rock massif located between the ore bodies.In the calculations of shock impacts on the safety cushion, only the volumes of the collapsed pit edges of a given height, width and volume were used, while the possibility of collapse of the inter-ore rock massif was not considered. Currently, there are no reliable methods for predicting large-scale rock collapses during outcropping with mining of the rock massif located between the EOB and WOB. Meanwhile, at the final stage of the development of the Udachnaya pipe, the height of the collapsed rocks of this massif will amount to 600-700 meters.

\section{CONCEPT OF SAFE UNDERGROUND MINING}

Figure 3 shows a diagram illustrating the development of the destruction processes of the rock massif located between the EOB and WOB for various stages of mining of ore bodies. 


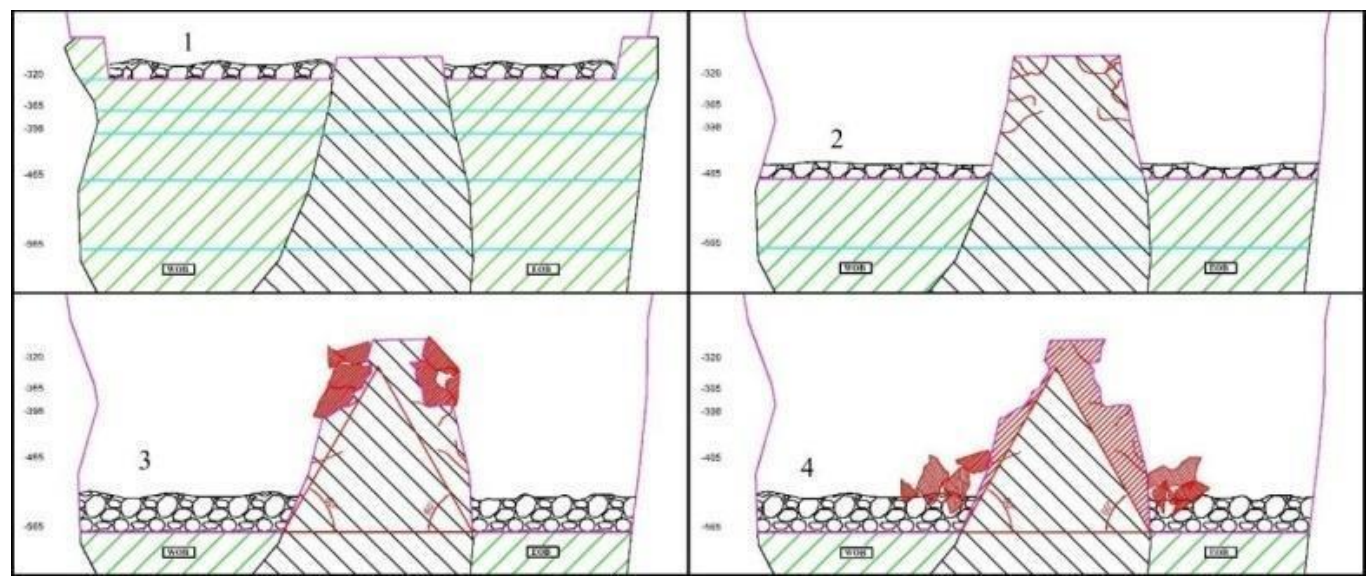

Fig. 3. The predicted process of collapse of the rock mass located between the WOB and EOB: 1 safety cushion before the start of the 1st level mining; 2,3,4 - safety cushion after working on the 1st, 2nd and 3rd level.

\section{RECOMMENDATIONS FOR RESEARCH}

To ensure the safety of underground mining operations at the Udachny Mine, it is recommended to implement a set of activitieson the forced collapse of the rocks of the edge part of the massif located between the ore bodies, onto the safety cushion by drilling and blasting operations. In so doing, the parameters of drilling and blasting operations must be adjusted to exclude the impact of collapsed rock blocks on the state of underground workings and to exclude dangerous pressure drops at the outlet of air waves from the safety cushion to underground mine workings. The purpose of such mining and blasting operations is the controlled movement of rocks by explosive force onto the safety cushion.

The main parameters required for implementing these activities are correct estimates of the values of the required dimensions of the rock pieces, which will enable moving pieces of rock by an explosion at a distance of up to 100-200 meters and preserving the properties of loose rock in the blasted rock mass.

Blasting operations should be carried out with minimum possible lagging behind the excavation progress.

To assess the capacity of moving rocks onto the safety cushion, it is necessary to know the minimal, maximal and average dimensions of rock pieces and their throw during blasting.

This is an external ballistics problem, andin the first approximation its solution looks plausible due to theapplication of the calculation methods specified in [23, 24, 25].

The main assumption in the solution of this problem is that the air resistance force vector should be directed opposite to the velocity vector.

This assumption is based on rock pieces rotation in the flight; this rotation does not end until the rock pieces fall down onto the safety cushion.

This rotation offsets the resulting windage which will inevitably cause deviation of the resistance force from the direction of movement.

Along with offsetting the windage, rotation also offsets the resistance force of motion in either direction of the coordinate axes, since rotation averages out any resistance of the kinetic components. 
Thus, the equation for individual pieces of rock of the movable massif can be deduced in vector form as follows:

$$
\frac{d \vec{v}}{d t}=-b_{c} v \vec{v}+\vec{g}
$$

where $\mathrm{v}$ is the motion speed $(\mathrm{m} / \mathrm{s})$; $\mathrm{g}$ is acceleration due to gravity $(\mathrm{m} / \mathrm{s} 2) ; \mathrm{t}$ is time $(\mathrm{s}) ; b_{c}$ is the friction factor $(1 / \mathrm{m})$.

$$
b_{c}=C_{L} \frac{\gamma S}{2 \rho V}
$$

where $C_{L}$ is the coefficient taking into account the rock piece shape; $C_{L}$ is approximately equal to 1 for a spherical type surface; $\gamma$ is the density of the medium (air) $(\mathrm{kg} / \mathrm{m} 3)$; $\mathrm{S}$ is drag area of body in motion; $\rho$ is the density of a piece of rock $(\mathrm{kg} / \mathrm{m} 3)$; $\mathrm{V}$ is the volume of a piece of rock $(\mathrm{m} 3)$.

When constructing an analytical model for the throw of rock during an explosion, the parameters of velocity and distance are taken into account. The correlation between the speed of a rock piece andits dimensions is established by an equation in the direct coordinate system. The $y$ axis isdirected upward, the $\mathrm{x}$ axis extends along the horizon of the rock motion.With the designation as the components of the speed on the axes, the following system of equations is derived:With the designation of $v_{x}$ and $v_{y}$ as the velocity components on the axes, the following system of equations is deduced:

$$
\left\{\frac{d v_{x}}{d t}=-b_{c} v_{x} v ; \quad \frac{d v_{y}}{d t}=-b_{c} b_{c} v-g ; \frac{d x}{d t}=v_{x} ; \quad \frac{d y}{d t}=v_{y} .\right.
$$

where $v=\sqrt{v_{x}^{2}+v_{y}^{2}}$, and the initial conditions for the integration of this system of equations are as follows: $\mathrm{t}=0, v_{x}=v_{0} \cos \cos \theta_{0}, v_{x}=v_{0} \cos \cos \theta_{0}, v_{y}=v_{0} \cos \cos \theta_{0}$, $\mathrm{x}=0, \mathrm{y}=0, \mathrm{x}=0, \mathrm{y}=0$, where $\theta$ is the jump angle of a piece of rock in relation to the horizontal $\mathrm{x}$-axis.

The resulting system of equations is further considered in an oblique coordinate system (Fig. 4): 


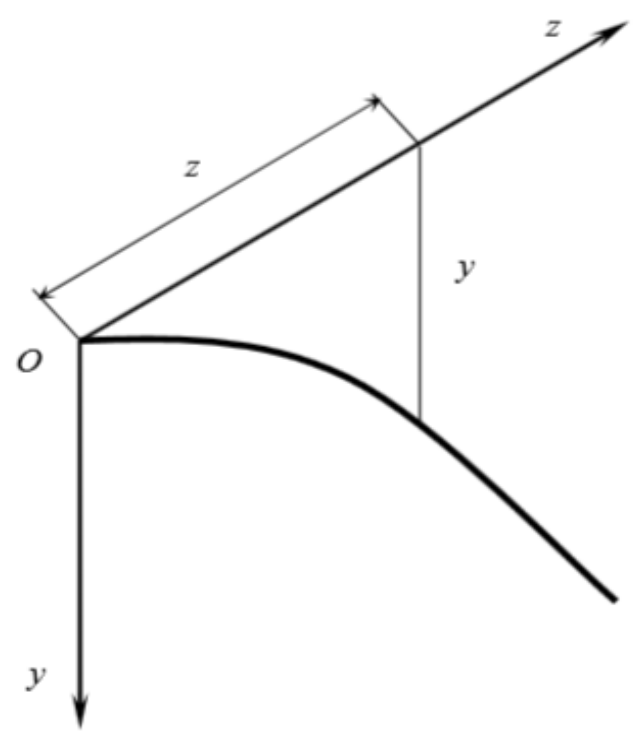

Fig. 4. Oblique coordinate system.

Here $\mathrm{z}$ is the coordinate axis directed along the initial velocity vector; $\mathrm{y}$ is the coordinate axis with the direction along the vector of the gravity force. The initial conditions for this system are as follows: $\mathrm{t}=0, \mathrm{z}=0, \mathrm{y}=0, v_{z}=v_{0}, v_{y}=0$.

After simplifying the system, we receive two independent differential equations:

$$
\left\{\frac{d^{2} z}{d t^{2}}=-b_{c} v_{z}^{2} ; \quad \frac{d^{2} y}{d t^{2}}=g-b_{c} v_{y}^{2}\right. \text {. }
$$

where $v_{y}$ and $v_{z}$ are the velocities of independent axial movements, while the initial conditions of the system are the same: $\mathrm{t}=0, \mathrm{z}=0, \mathrm{y}=0, v_{z}=v_{0}, v_{y}=0$.

Experts using this technique have formed an approximate graph of the dependenceof the initial velocity of rock pieces on their weight (Fig. 5):

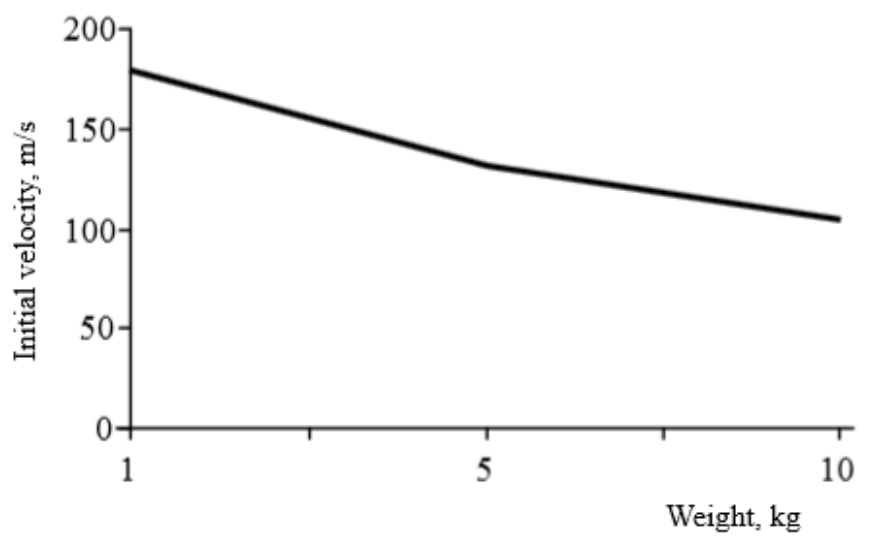

Fig.5. Graph of the initial velocity of rock pieces in relation to their weight. 
To carry out calculations applicable to the conditions of Udachnaya pipe, the following basic parameters are to be adopted:

1. The limit dimensions of a piece of blasted rock mass capable of guided moving from the rock massif towards the safety cushion are about $1,000 \mathrm{~mm}$, there is a direct correlation between the rock piece dimensions and its location in the rock massif. The closer proximity of the rock massif center is, the smaller dimensions of a piece of blasted rock mass are required for this purpose. This correlation is exponential, to extent of extremely fine fractions.

2. The minimum velocity of rock pieces which can reach the safety cushion, ranges from 100 to $200 \mathrm{~m} / \mathrm{s}$. The piece of rock initial velocity below $100 \mathrm{~m} / \mathrm{s}$ will not have the capacity to effectively transport the rock mass up to the safety cushion.

To calculate the maximum throw distance of rock fragments, the initial equation can be as follows:

$$
\begin{aligned}
& \left\{\ddot{x}=-b_{c} \dot{x}^{2}, \quad \ddot{y}=-b_{c} \dot{y}^{2}-g, y \geq 0\right. \\
& \left\{\ddot{x}=-b_{c} \dot{x}, \quad \ddot{y}=-b_{c} \dot{y}^{2}+g, y \leq 0\right.
\end{aligned}
$$

where $\dot{x}$ is differentiation according to time, while the initial conditions for integrating this system of equations are follows: $\mathrm{x}(0)=y(0)=0, \dot{x}(0)=\dot{x}_{0}=v_{0} \cos \cos \theta_{0}$, $\dot{y}(0)=\dot{y}_{0}=v_{0} \sin \sin \theta_{0}, \theta-$ jump angle of a piece of rock in relation to the horizontal $\mathrm{x}$-axis. The solution of these systems of equations is as follows:

$$
\left\{\mathrm{x}=\frac{1}{b_{c}}\left(\ln \ln \left(1+b_{c} \dot{x} t\right), \quad y=\frac{1}{b_{c}} \ln \ln \left(\cos t \sqrt{g b_{c}}+\dot{y}_{0} \sqrt{\frac{b_{c}}{g}} \sin \sin t \sqrt{g b_{c}}\right), y \geq 0\right. \text {; }\right.
$$

$$
\left\{\mathrm{x}=\frac{1}{b_{c}}\left(\ln \ln \left(1+b_{c} \dot{x t}\right), \quad y=\frac{1}{b_{c}} \ln \ln \left(\operatorname{cht} \sqrt{g b_{c}}+\dot{y}_{0} \sqrt{\frac{b_{c}}{g}} t \sqrt{g b_{c}}\right), y \leq 0\right. \text { (1). }\right.
$$

When a piece of rock moves, its path goesalong the x-axis (Fig. 6). For path continuity in Equation 1, the ordinate direction will be reversed. Provided that time is removed from the system, the following equation is deduced:

$$
y=\frac{1}{b_{c}} \ln \ln \left\{\cos \left[\frac{1}{\dot{x}_{0}} \sqrt{\frac{g}{b_{c}}}\left(e^{b_{c} x}-1\right)\right]+\dot{y}_{0} \sqrt{\frac{b_{c}}{g}} \sin \left[\frac{1}{\dot{x}_{0}} \sqrt{\frac{g}{b_{c}}}\left(e^{b_{c} x}-1\right)\right]\right\}
$$

In order to calculate the $x_{\max }$. value, the x-coordinate of the extreme point of the path graph should be found and multiplied by 2 . 


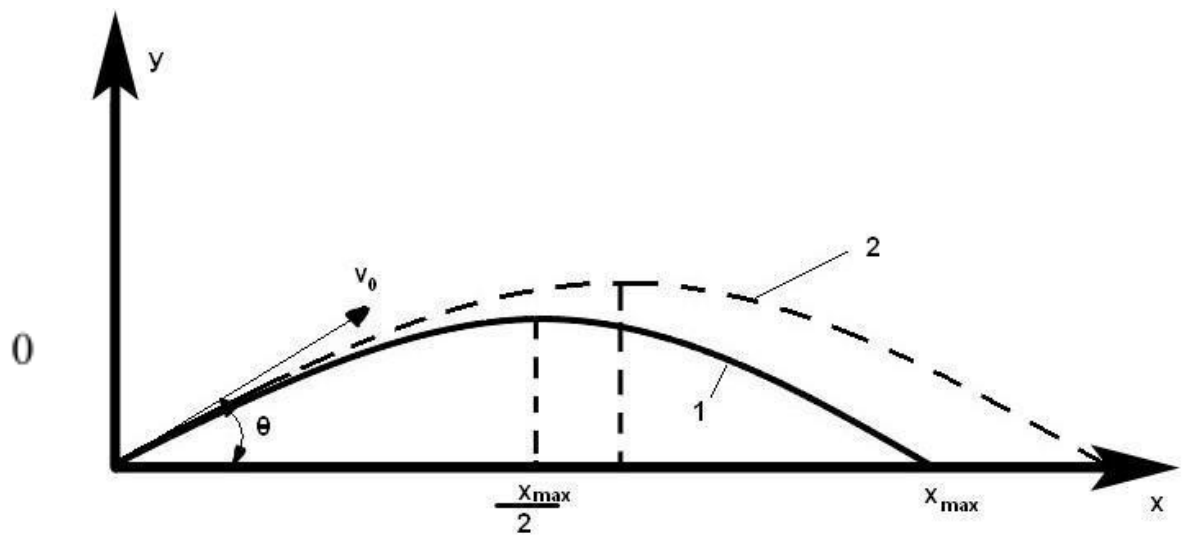

Fig. 6. The path of a piece of rock in the blast: 1 - with consideration of the air resistance; $2-$ in vacuum.

Simplifying Equation 2 [26, 27, 28, 29], we can find the maximum flight range of a piece of rock:

$$
x_{\max }=\frac{2}{b_{c}} \ln \left[1+\dot{x}_{0} \sqrt{\frac{b_{c}}{g}} \operatorname{arctg}\left(\dot{y}_{0} \sqrt{\frac{b_{c}}{g}}\right)\right] .
$$

This formula enables calculation of the correlation between the maximum scattering length and the dimensions of a piece of rock. The calculation results are shown in Table 1:

Table 1. Maximum scattering length of rock pieces of different dimensions

\begin{tabular}{|l|l|l|l|l|l|}
\hline № & $\begin{array}{l}\text { Fit-for-purpos } \\
\text { e piece, } \mathrm{m}\end{array}$ & Volume, $\mathrm{m}^{3}$ & $\mathrm{Bc}$ & $\begin{array}{l}\text { Weight, } \\
\text { tons }\end{array}$ & $\begin{array}{l}X_{\text {max }} \\
\mathrm{m}\end{array}$ \\
\hline 1 & 0 & 0 & 0 & 0 & 0 \\
\hline 2 & 0.05 & 0.000125 & 0.000 & 0.000 & 735.7 \\
\hline 3 & 0.1 & 0.001 & 0.000 & 0.003 & 701.0 \\
\hline 4 & 0.15 & 0.004 & 0.001 & 0.009 & 695.3 \\
\hline 5 & 0.2 & 0.008 & 0.002 & 0.021 & 620.9 \\
\hline 6 & 0.25 & 0.016 & 0.005 & 0.041 & 438.7 \\
\hline 7 & 0.3 & 0.027 & 0.011 & 0.070 & 268.7 \\
\hline 8 & 0.35 & 0.043 & 0.021 & 0.111 & 185.8 \\
\hline 9 & 0.4 & 0.064 & 0.036 & 0.166 & 123.0 \\
\hline 10 & 0.45 & 0.091 & 0.058 & 0.237 & 84.7 \\
\hline 11 & 0.5 & 0.125 & 0.088 & 0.325 & 60.2 \\
\hline 12 & 0.55 & 0.166 & 0.128 & 0.433 & 44.0 \\
\hline 13 & 0.6 & 0.216 & 0.182 & 0.562 & 33.0 \\
\hline 14 & 0.65 & 0.275 & 0.251 & 0.714 & 25.2 \\
\hline 15 & 0.7 & 0.343 & 0.337 & 0.892 & 19.6 \\
\hline 16 & 0.75 & 0.422 & 0.444 & 1.097 & 15.5 \\
\hline & & & & & \\
\hline
\end{tabular}




\begin{tabular}{|l|l|l|l|l|l|}
\hline 17 & 0.8 & 0.512 & 0.575 & 1.331 & 12.4 \\
\hline 18 & $0 . .85$ & 0.614 & 0.733 & 1.597 & 10.1 \\
\hline 19 & 0.9 & 0.729 & 0.921 & 1.895 & 8.2 \\
\hline 20 & 0.95 & 0.858 & 1.144 & 2.229 & 6.8 \\
\hline
\end{tabular}

The maximum scattering length for a fit-for-purpose piece of rock of $700 \mathrm{~mm}$ in the dimensions will be as follows:

$$
\begin{gathered}
b_{c}=0,9 \frac{1,2 \cdot 0,7}{2 \cdot 2,6 \cdot 0,343}=0,337 \\
x_{\text {max }}=\frac{2}{b_{c}} \ln \left[1+v \cdot \cos (\propto) \sqrt{\frac{b_{c}}{g}} \operatorname{arctg}\left(v \cdot \sin (\alpha) \sqrt{\frac{b_{c}}{g}}\right)\right],
\end{gathered}
$$

where $\mathrm{v}$ is the minimum jump velocity of a piece of rock equal to $175 \mathrm{~m} / \mathrm{s}$, whilecos $(\propto)$ and $\sin (\alpha)$ are the jump angles of a piece of rock in the blast, equal to 45 degrees (the most adverse conditions).

$$
x_{\text {max }}=\frac{2}{0,337} \ln \left[1+175 \cdot \cos (45) \sqrt{\frac{0,337}{9,81}} \operatorname{arctg}\left(175 \cdot \sin (45) \sqrt{\frac{0,337}{9,81}}\right)\right]=19,6 \mathrm{~m} \text {. }
$$

Hence, a large piece of rock $(700 \mathrm{~mm})$ can scatter over a 20-meter distance. Smaller pieces can scatter over longer distances, up to hundreds of meters. The performed calculations enable to assume the plausibility of uniform guided movement of rocks onto the safety cushion.

\section{CONCLUSION}

The factors that significantly increase the risks of underground mining of the Udachnaya pipe pit reserves with the use of forced caving and areal ore drawing under the safety cushion, include:

1.Low stability of the rock massif located between the closely spaced Eastern Ore Body and Western Ore Body, and the high probability of collapse of sizeable rock blocks from the edge zones of this rock massif onto a safety cushion.

2. Dynamic collapse of sizeable rock blocks from the edge zones of the rock massif located between the ore bodies onto the safety cushion can lead to loss of stability.

of underground mine workings and occurrence of dangerous pressure drops at the outlet of air waves from the safety cushion into the underground mine workings. The weight of collapsing rock blocks can be $0.4-0.6$ tons or more, the drop height is up to $200 \mathrm{~m}$ or more.

3. To prevent dangerous impact blows on the safety cushion, it is recommended to implement forced collapse of the edge part rocks of the massif located between the ore bodies onto the safety cushion by means of drilling and blasting operations. At the same time, it is necessary to adjust the parameters of drilling and blasting operationsto exclude the impact of collapsed rock blocks on the state of underground workings and exclude dangerous pressure drops at the outlet of air waves from the safety cushion to the underground workings.

4. Areas of further research in the implementationof the considered method of safety enhancement of the underground mining operations at the Udachny Mine, with the 
currently applied mining method, include the determination of the rational parameters of drilling and blasting operations thatwill ensure the prevention of dangerous impact blows and enable the required distribution of the rock mass on the safety cushion.

\section{REFERENCES}

1. Tishkov M. 2018. Evaluation of caving as mining method for the Udachnaya underground diamond mine project. Caving 2018: pp. 835-846.

2. Kovalenko, A. A. \&ikh, I.L. 2016. Improving the technology of mining reserves of the Udachnaya pipe using development systems with self-collapse of ore. Innovative geotechnologies in the development of ore deposits: pp. 69-74.

3. Kosukhin, N.I. \&Sidorov, D.V. \&Beloglazov, I.I. \&Timofeyev, V. Y. 2019. AssessmentofStress-StrainandShockBumpHazardofRockMassintheZonesofHigh -AmplitudeTectonicDislocations. IOP Conference Series: Earth and Environmental Science (Vol 224): pp.1-5.

4. Nikitin, I.V. 2017. Optimization of opening parameters during underground mining of open-pit reserves of a kimberlite deposit. Topical Issues of Rational Use of Natural Resources (1) pp. 21-28.

5. Kovalenko, A.A. \&Tishkov, M.V. 2016. Evaluation of development of the Udachnaya pipe field. Mining Information and Analytical Bulletin (12): 173-174.

6. Chadwick, J. 2012. Automated Finsch. International Mining: pp/ 10-13.

7. Jacques, J-S. Thompson, S. 2019. Rio Tinto Interim Results 2019. England: Rio Tinto.

8. Zuev, B.Yu. \&Zubov, V.P. \&Fedorov, A.S. 2019. Application prospects for models of equivalent materials in studies of geomechanical processes in underground mining of solid minerals. Eurasianmining (1): 8-12.

9. Trushko, V.L.\&Protosenya, A.G. 2019. Prospects of geomechanics development in the context of new technological paradigm. NotesofMiningInstitute (Vol. 236): pp. 162-166.

10. Chaadaev, A.S. \&Zyryanov, I.V. \&Bondarenko, I.F. 2017. State and prospects of development of mining technologies at diamond mining enterprises of PAO Alrosa. Mining Industry (2): pp. 6-13.

11. Balek, A.E. \&Efremov, E.Yu. 2016. Justification of the geomechanical conditions of the underground mining of the Udachnaya diamond pipe. Innovative geotechnologies in the development of ore deposits: pp. 173-176.

12. Kovalsky, E.R. \&Leisle, A.V. \&Karpov G.N. 2020. Evaluation of displacements of the mine workings contour in abutmen tpressure zones. International Journal of Advanced Science and Technology (Vol 29): pp. 1951-1959.

13. Drozdov, A.V. 2009. Geotechnological problems of developing the deep horizons of the Udachnaya pipe. Subsoil use problems: issues of integrated development of deep-seated mineral deposits: pp. 110-121.

14. Drozdov, A.V. 2011. Mining and geological features of the deep horizons of the Udachnaya pipe. Mining Information and Analytical Bulletin (1): pp. 153-165.

15. Bartlett, S.C. 2018. Brief report by independent experts on the reserves and resources of diamond deposits of the ALROSA group of companies. England: Micon International Co Limited. 
16. Balek, A.E. \&Sashurin, A.D. 2019. The problem of assessing the natural stress-strain state of a rock mass during subsurface development. Mining Information and Analytical Bulletin (special issue): pp. 9-23.

17. Bokiy, I.B. \&Zoteev, O.V. \&Pul', V.V. 2019. Analysis of the process of subsidence of the rock cushion during mining of the western ore body of the Udachnaya pipe using a collapse system. Mining Journal (2):pp. 43-46.

18. Jakubec J. \&Legace D. \&Boggis B. \& Clark L.M. \& Lewis PA. 2018. Underground mining at Ekati and Diavik diamond mines. Caving 2018: pp. 73-88.

19. Piven', G.F. 2011. Technologies for the development of sub-quarry reserves of the Udachnaya pipe. Notes of the Mining Institute (1): pp.359-361.

20. Carlson, J.A. 2016 Ekati diamond mine, Northwest Territories, Canada, NI 43-101 Technical report.

21. Sokolov, I.V. \& Smirnov, A.A. \&Antipin, Yu.G. \&Nikitin, I.V. \&Tishkov, M.V. 2018. Justification of the thickness of the safety cushion when working out the quarry reserves of the Udachnaya pipe with caving systems. Technology mining operations (2): pp. 52-62.

22. Slyshenko I.I. \&Mishedchenko O.A. 2018. Reasons of the rock massive deformations in the underground developing of the Udachnaya pipe of Alrosa. Mine surveying and subsurface use №1 (93): pp. 24-31.

23. Cleaver, B. 2019. The Diamond Insight Report 2019. England: De Beers Group.

24. Drozdov, A.V. 2015. Mining, geological and technological problems in the construction of the Udachnaya underground mine. Mining Information and Analytical Bulletin (2): pp. 125-131.

25. Kostrovitsky S.I. 2010. What is kimberlites? Materials of the 6th International School of Earth Sciences ISES-2010: pp. 77-81.

26. Pokrovsky, G.I. \&Fedorov, I.S. 1971. Erection of hydraulic engineering earthworks with a directed explosion. Moscow: Nedra.

27. Yakubovskiy, M.M.Sankovsky, A.A. 2017. Drilling and blasting design based on invariable mining parameters. JournalofIndustrialPollutionControl (Vol. 33): pp. 931-936.

28. Zharovkin A.V. 2009. Improving the technology of calculating dangerous distances by scattering pieces of rocks during massive explosions in open pits. Notes of the Mining Institute (Vol.180): pp. 135-139.

29. Zuev, B.Yu. \&Zubov, V.P. \&Smychnik, A.D. 2019. Determination of static and dynamic stresses in physical models of layered and block rock masses. Mining Journal (7): pp. 61-70. 